\title{
Form and meaning of ornamental variety elements in the interior style of batik kitchen café and restaurant in Cirebon
}

\author{
Rosiana ${ }^{a}, 1$, Indarto $a, 2^{*}$ \\ ${ }^{a}$ Institut Seni Indonesia Surakarta, Indonesia. \\ 1 rosiana073@gmail.com, ${ }^{2}$ interior.hanindart@gmail.com. \\ * Corresponding Author
}

Received 18 October 2021; accepted 24 November 2021; published 13 December 2021

\begin{abstract}
Batik Kitchen Café and Restaurant is a culinary-related commercial building in Cirebon. Batik Kitchen Café and Restaurant in Cirebon applies decorative elements in the form of batik to its interior style. The application of decorative elements to the interior style of Batik Kitchen Café and Restaurant is found in the elements that form and fill the space. This study aims to determine the application, decoration, and meaning of the decorations in the interior of Batik Kitchen Café and Restaurant in Cirebon. To answer the problems in the study, the interior design approach the theory of D.K. Ching, and Roland Barthes' approach to meaning. The research was conducted with a qualitative descriptive method. This qualitative research is directed at the real conditions of the research object. The data sources of this research are sources (informants), objects, records, literature, and the internet. The results showed: (1) The application of decorative elements in the form of batik was found in space; lobby area, dining room, and bar area, in the form of space-forming elements; floors, walls, and ceilings, as well as space fillers; tables and chairs, as well as interior accessories. (2) The decorative elements applied to the interior style of Batik Kitchen Café and Restaurant in Cirebon is Nusantara batik motifs which have various meanings. The application of decorative elements to the interior style of the Batik Kitchen Cafe and Restaurant in Cirebon which plays a role in introducing, promoting, and preserving the traditional and cultural values of Cirebon City.
\end{abstract}

\section{KEYWORDS}

Forms

Meanings,

Decorative

Elements,

Batik Kitchen.

This is an openaccess article under the CC-BY-SA

license

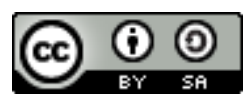

\section{Introduction}

Cirebon city is one of the cities in West Java established since 1388, is a city that has a lot of ethnic and cultural diversity in it,(Nurhayati \& Nurhidayah, n.d.) . Cirebon city is one of the cities in Indonesia that is famous for its batik production. Batik Cirebon has a difference compared to other batik producing cities such, (Handayani, 2019) as Batik Yogyakarta, Solo, Pekalongan, and Madura, . The city of Cirebon has a traditional batik center located in the batik tourist area, namely Trusmi Village. In line with the development of Cirebon batik in Trusmi, currently, Trusmi Village becomes the center of batik industry in Cirebon as well as a shopping spot for tourists that sells traditional batik and typical culinary of Cirebon city. The development of tourism in Trusmi Village makes this area develop into a promising entrepreneurship center, so that many commercial buildings are established in the area. One of the commercial buildings in Trusmi region is Batik Kitchen Café and Restaurant. Batik Kitchen Café and Restaurant is a commercial building engaged in the culinary field, on Jalan Trusmi Kulon No. 148, Plered, Cirebon, West Java which was established in 2016. As the name implies, Batik Kitchen Café and Restaurant, this building displays elements of a strong ornamental variety in the form of batik that affects the interior style. Elements of ornamental variety found in café and restaurant is the motif of mega mendung batik (Trihanondo et al., 2021), kawnng batik (Nursalim \& Sobandi, 2020), parang batik (Borshalina, n.d.) , sidomukti batik (Sunarya \& Anas, 2011), truntum batik. (Widodo et al., 2021), and slobog batik, (Ramdoni et al., 2019). But what dominates the interior style of Batik Kitchen Café and Restaurant is motif which is a 
typical batik motif of Cirebon City. Ornamental variety elements in Batik Kitchen Café and Restaurant are applied to several elements of space forming and fillers, the application of this ornamental variety element can be found in public areas such as lobby, dining room, and bar area. The application of ornamental variety elements in the form of batik in Batik Kitchen Café and Restaurant presents a traditional style in interior design. This traditional style became an identity for Batik Kitchen Café and Restaurant, (Shuang, 2012). With the application of ornamental variety elements in the interior style makes this café and restaurant has a distinctive identity that differs from other cafés and restaurants. The presence of a strong ornamental variety element in the interior style of Batik Kitchen Café and Restaurant in Cirebon encourages writers to examine the form of application and meaning of ornamental variety elements applied in the interior style of Batik Kitchen Café and Restaurant in Cirebon. This research aims to find out the application of ornamental variety elements, as well as the meaning of ornamental variety elements in the interior style of Batik Kitchen Café and Restaurant in Cirebon.

\section{Method}

This research was conducted with descriptive qualitative methods. With this descriptive qualitative research, the research topic is directed at the original condition of the research object, as well as the quality of interactions that occur during the research so that researchers can present a realistic picture of the actual situation to support the data presentation. To answer the problems in the research, the interior design approach of D.K. Ching theory was used, and the approach to the meaning of Roland Barthes theory, (Allen, 2004). D.K. Ching interior design approach is to answer the technique of applying ornamental variety elements to interior styles, by considering the elements and principles of interior design, (Docci \& Chiavoni, 2014). The theoretical meaning approach of Roland Barthes is to investigate the meanings contained in ornamental variety elements. The application of Roland Barthes theory is done by dissecting and interpreting the meaning of ornamental variety by looking at the meaning of denotation, and its connotations. This research data was gathered from sources (informants), items, recordings, literature, and the internet. This research is focused on spaces that display ornamental variety elements in the interior of the space. This study employs in-depth interview approaches, direct observation, and literature reviews, (Rosenthal, 2016).

\section{Results and Discussion}

The interior style of Batik Kitchen Café and Restaurant is dominated by a strong ornamental diversity element, which in this case is batik. This ornamental variety element is used in space forming and space filler elements, with distinct ornamental variety elements in each element. The areas include the lobby, dining room, and bar area. Figure 1.

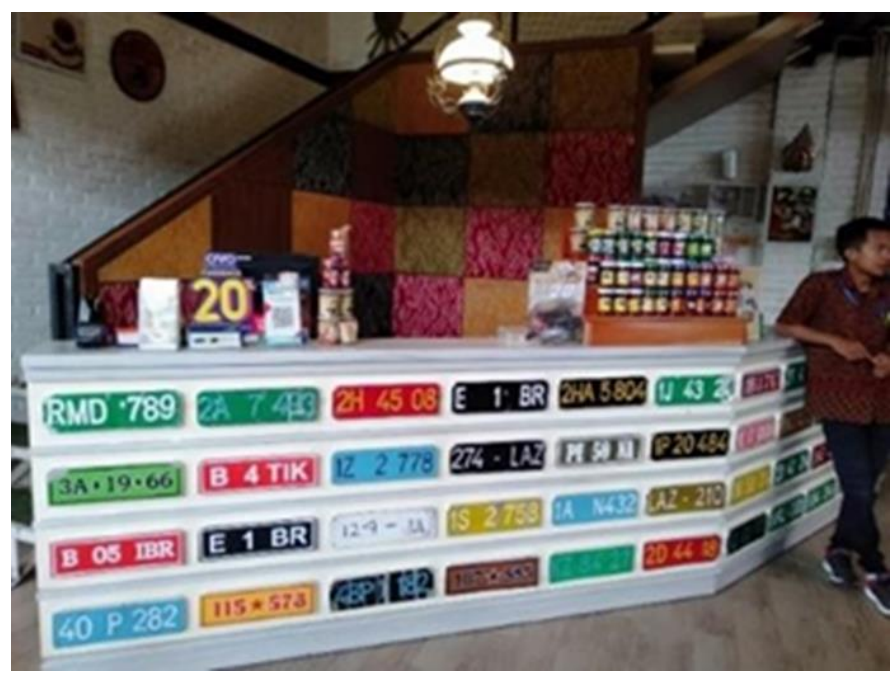

Fig. 1. The Lobby of Batik Kitchen Café and Restaurant. As background ornaments, there are several batik themes.

Ornamental variety elements in the bar area are found on the floor, walls, ceiling, and tables. While in the dining room, the ornamental variety elements look very dominating the interior of the room, they are applied to the floor, walls, ceiling, tables, chairs, and accessories. The bar area is the last part of Batik 
Kitchen Café and Restaurant which has ornamental elements in the interior. Ornamental variety elements can be found on the bar table, and interior accessories attached to the walls. Figure 2 .

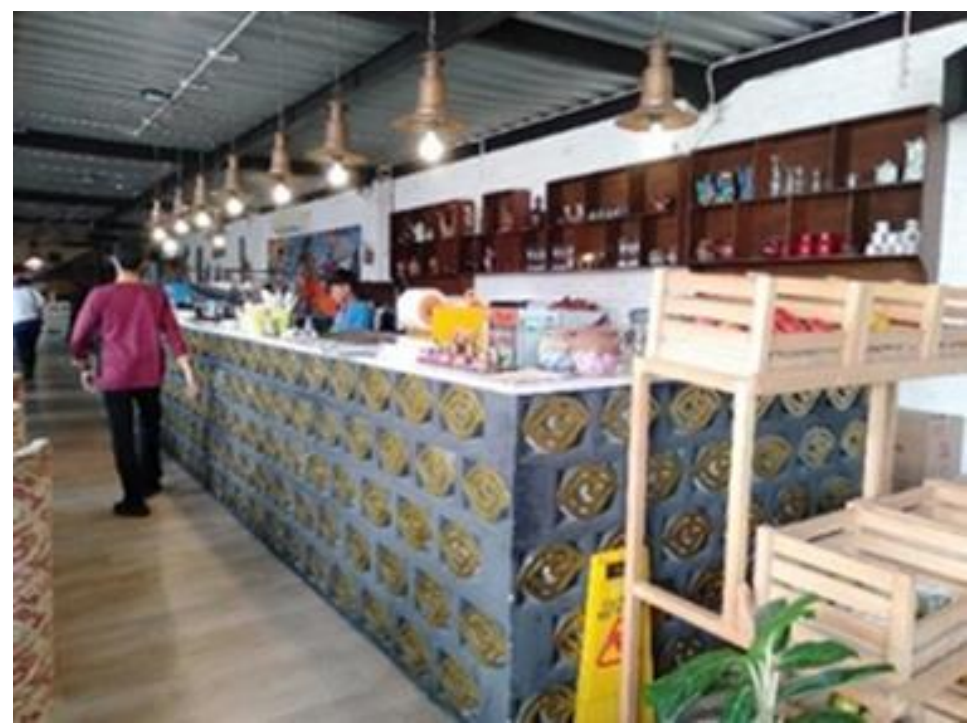

Fig. 2. Dining Room Batik Kitchen. ornament on the table with a basic yet appealing composition that offers a sense of the interior theme.

To answer the technique of applying ornamental variety elements to the interior style of Batik Kitchen Café and Restaurant in Cirebon, this study uses the interior design approach of D.K. Ching theory by looking at elements and principles of interior design. Lobby is an area that contains elements and principles of interior design in the technique of applying every ornamental variety element contained in the interior style of Batik Kitchen. Elements of interior design that form an ornamental variety in the lobby area consist of lines, fields, colors, light dark, and textures, (Lauer \& Pentak, 2011). To achieve a good composition, the use of ornamental types, in the lobby area, takes account interior design concepts. The principles used in the application of ornamental varieties in the lobby area are unity, balance, proportion, rhythm, focal point, and detail (Sumarno \& Indarto, 2018). Dining room is an area that has elements and principles of interior design in every element of ornamental variety applied to the interior style of Batik Kitchen Café and Restaurant in Cirebon. The elements of interior design that form an ornamental variety in the dining room area consist of lines, fields, shapes, colors, light dark, and textures. Field elements contained in the variety of ornamental dining room in the form of paintings on the wall, two-dimensional works, and elements of shapes on tables, chairs, and pillow chairs that have a shape resembling cubes and cylinders. Figure 3. In one of the surfaces of glass walls in the room there is a sandblast sticker with mega mendung batik motif applied using sticking techniques. According to Lindi, the application of sandblast stickers with this motif, beside to beautify the glass walls in Batik Kitchen Café and Restaurant in Cirebon, it is also an effort to civilize the mega mendung batik which is a typical motif of Cirebon City. The application of ornamental varieties in the lobby area considers the principles of interior design to obtain a good composition. The principles used in the application of ornamental varieties in the lobby area are unity, balance, rhythm, focal point, and detail. The bar area is one of the areas that apply ornamental variety in which contains elements and principles of interior design in every element of ornamental variety applied to the interior style of Batik Kitchen Café and Restaurant in Cirebon. Elements of interior design that make up the ornamental variety in the bar area consist of lines, fields, shapes, colors, and textures. The bar table in the bar area is one of the focal points in the interior style of Batik Kitchen Café and Restaurant, with the shape of cloud blobs, and firm colors such as black and gold make the bar table an attractive focal point for visitors. 


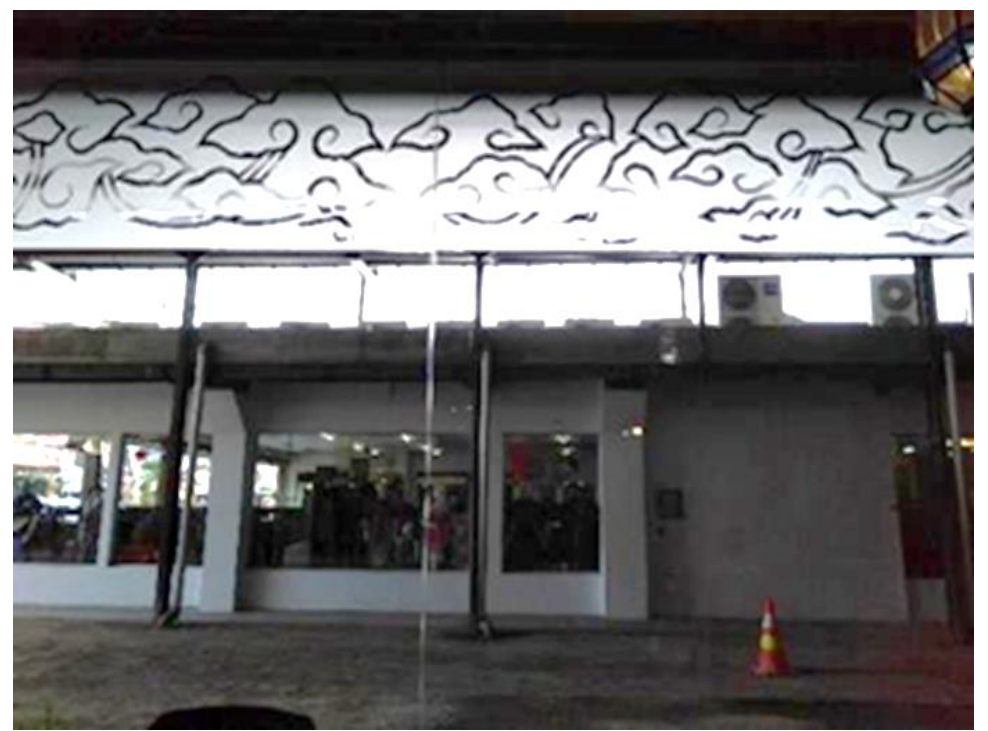

Fig. 3. Sandblast stickers with mega mendung motifs. ornaments on the main entrance with a basic yet appealing composition that offer a sense of the interior theme. The design is appealing enough that it can notify clients who come in about the object's existence

Batik Kitchen Café and Restaurant in Cirebon has an ornamental variety element in the form of batik. Batik applied to the interior of Batik Kitchen Café and Restaurant consists of a variety of different batik motifs. Every batik motif that exists is batik Nusantara that has its origin, history, and meaning in it. Batik motifs in Batik Kitchen Café and Restaurant in Cirebon are batik motifs of mega mendung, kawung, parang, truntum, sidomukti, sriwedari, and slobog. But among the mentioned batik motifs, mega mendung batik motif dominates interior styles at Batik Kitchen Café and Restaurant in Cirebon. Every aesthetic variation feature of the Batik Kitchen Café and Restaurant in Cirebon has a value. The diversity of motifs in the interior style of Batik Kitchen Café and Restaurant in Cirebon provides high artistic and cultural value. Batik, a decorative variation element with aesthetic value, also has symbolic implications that are beneficial to human existence. The motif and color parts of batik's symbolic meaning can be evaluated separately. Mega mendung motif is the original batik motif of Cirebon City, which was created by Prince Cakrabuana. This pattern is a fusion of Cirebon and Chinese culture, which is then tailored to the Cirebon people's tastes, that are predominantly Muslim. Mega mendung batik motif belongs to nongeometric batik motifs or ornamental motifs with irregular shape. Non-geometric shapes are shapes that mimic nature, such as animals, plants, and humans. Mega mendung motifs include non-geometric fauna for its shape that is in the form of cloud clumps. The characteristics of mega mendung are found in the motif that is shaped like a clumpy cloud. This mega mendung motif represents the long-awaited rain carrier that will bring fertility and life to the land.

To answer the meaning contained in the mega mendung batik motif at Batik Kitchen Café and Restaurant in Cirebon, it will be reviewed in terms of function, and in terms of shape. The mega mendung batik motif generally serves as a fashion within the scope of Cirebon palace. Over time, this batik motif undergoes a shift in function, not only functioning as fashion but also functioning in everyday life, as is the case of mega mendung batik motif applied to the interior style of Batik Kitchen Café and Restaurant in Cirebon. Broadly speaking, this batik motif at Batik Kitchen Café and Restaurant in Cirebon serves as building the identity of Batik Kitchen. Such motif dominating the interior design of this Batik Kitchen building has the aim to create a typical style of interior with the local value of Cirebon City. The kinds of mega mendung batik motifs are mega mendung motifs of plain clouds, mega mendung with butterflies combination, and mega mendung with shrimp combination. Kawung batik motif is a geometric batik motif with ceplokan or ceplok (circle-shaped) pattern. Ceplok, for decoration, can be interpreted as a circle. The ceplok pattern consists of one motif arranged repeatedly. Kawung motif also has a symbolic meaning in the roundness depicted in the form of circles on the motif, which means full determination. This kawung batik motif is found on the floor and in batik kitchen café and restaurant tables. Kawung Batik motif is one of the exclusive (prohibited for common people) motifs, meaning that this batik motif should only be worn by people who come from the palace. But over time now kawung batik motifs can be worn by various circles of society. In addition to being worn, kawung batik motifs are widely interpreted in various 
aspects of life, one of which becomes an aesthetic element in a building. In the interior style of Batik Kitchen Café and Restaurant in Cirebon kawnung batik motif is used as one of the motifs in the space forming element, that is the floor, using ceramic material with size of $30 \mathrm{~cm} \mathrm{x} 30 \mathrm{~cm}$, and as a space filler element, a table. Kawnung batik motif in Batik Kitchen still has the basic shape of palm fruit seeds or is commonly known as kolang-kaling, but undergoes a transformation in its shape. If in general kawnng batik motif is applied to a piece of cloth, at Batik Kitchen Café and Restaurant in Cirebon, this motif is applied in the ceramic. The meaning of every color there in Batik Kitchen Café and Restaurant in Cirebon, soga color contains the meaning of modesty, and down to earth. Blue means trustworthy, orange has a meaning of spirit and creativity. The brown color means honesty and simplicity. The beige color means softness and unifier. White color has the meaning of holiness, honesty, and a sacred cleanliness of heart, in Javanese cosmology the white color is a symbol of goodness and water. Black color means calm, wise, and helpful character, (Tresnawati et al., 2020).

Parang motif is a geometric motif with a design pattern of narrow diagonal rows and with small patterns. The word parang comes from the Javanese word pereng which means slope, depicted in the form of curved lines resembling waves in the sea. This parang motif can be found at one of the tables at Batik Kitchen Café and Restaurant. Batik parang motif has now undergone a shift in function, where in ancient times this batik motif should only be used by royal members for special events, but currently the parang batik motif can be used by the wider community for various purposes. Nowadays parang batik motifs are generally worn for clothing elements on important occasions such as official invitations, and so on. In addition to being used as clothing, parang motifs are often applied to some parts of the building, as happened to Batik Kitchen Café and Restaurant in Cirebon. The parang batik motifs at Batik Kitchen Café and Restaurant in Cirebon do not undergo a basic shape change. But what changes is the application of its shape. In Batik Kitchen parang motif is not applied to a piece of cloth, but is applied to the ceramic shape of motif measuring $15 \mathrm{~cm} \times 15 \mathrm{~cm}$. Truntum batik motif is a type of royal batik that includes nongeometric motifs with floral motifs or bouquets, the basic ornaments in the form of tanjung flowers (Mimusops elengi L.) shaped like stars. Truntum comes from the word taruntum which means to regather, which symbolizes the embrace or spirit of spousal love. Historically the truntum motif was created by Kanjeng Ratu Kencana who was a consort of Sunan Paku Buwana II.

This motif was created as a symbol of unconditional sincere love, and eternal love that is growing ever longer. This truntum motif is often worn by parents during wedding ceremonies. According to the view of the general public, truntum batik has the meaning of guiding, which means guiding both brides in entering marriage life. At Batik Kitchen Café and Restaurant in Cirebon, this batik motif is found in the elements of forming and filling the space in the form of floors and dining tables. The function of truntum batik motifs is not much different from the motifs that have been outlined above, this motif is often used as clothing for parents of brides in their child's wedding ceremony, for the use of this motif in the wedding ceremony symbolizes tumaruntum which means guiding. In addition to be used as clothing, truntum motifs are also used as ornamental variety elements in Batik Kitchen, where this motif is applied to ceramics, found on the floor, and the dining table of Batik Kitchen Café and Restaurant in Cirebon. Sidomukti motif is one of the names of inland batik motifs, which belong to the type of non-geometric motif, with semen patterns. Semen pattern is a pattern consisting of flora, fauna, meru (mountain-like), lar (wings), etc that are arranged in harmony. Sidomukti batik motif contains a noble philosophy that is prayers to both brides. The word Sidomukti comes from the Javanese language, which consists of two words, Sido and Mukti. Sido, in Javanese, means done or settled and Mukti mean prosperity. Sidomukti motif has a meaning expecting the wearers are to live prosperously. This motif is commonly used in traditional Javanese wedding ceremonies. This motif can be found on the floor and dining table of Batik Kitchen Café and Restaurant. At the dining table, the sidomukti motif looks full and intact, showing ornaments in it in the form of butterflies, bird wings, and throne-shaped buildings with a ceramic size of $15 \mathrm{~cm} \times 15 \mathrm{~cm}$. While on the floor, this motif only shows one of the ornaments, flower, with a ceramic size of $30 \mathrm{~cm} \times 30 \mathrm{~cm}$. The main ornament of this motif is the butterfly, which has the symbolic meaning of high and beautiful expectations. There are also ornaments in the shape of bird wings as a symbol of high expectations. Meru (mountain-like)-shaped ornament is a symbol of splendor, majesty like a large mountain, with dashing look. Floral motifs are defined as symbols of beauty. Sidomukti motif in Batik Kitchen consists of several colors, such as blue, beige, black, white, and brown soga. The color blue means peace, calm, and faithful. The color beige contains meaning as a tranquilizer in the room. White means holy, perfect, and clean. The brown color of soga means simplicity, down-to-earth, and honesty. Black has a virtuous symbolic meaning of noble, wise, and powerful. 
Sriwedari motif is a batik motif created to commemorate the establishment of a people's amusement park built during king of Pakubuwono X's reign in Surakarta Kasunanan. Sriwedari motifs belong to the type of non-geometric motif with a pattern of floral or bouquet motifs. This motif from Solo City is found on the ceramic floor of Batik Kitchen Café and Restaurant, with a size of $30 \mathrm{~cm} \times 30 \mathrm{~cm}$. Sriwedari motif is present on a dress, can be used by all status groups in society. Currently, sriwedari motif is not only applied in dress, but in Batik Kitchen which serves as one of space forming elements. The meaning of this motif symbolizes the coolness and inner peace of the family. The colors in the sriwedari motif are blue, beige, orange, and white. Each color has a different symbolic meaning. The blue color has a calm, and silent impression that symbolizes loyalty, calmness, and trustworthiness. Beige color symbolizes softness, giving the impression of classic, calm, and warm shades in the room. The orange color has the impression of full energy and fresh, symbolizing warmth, and high creativity. White has a clean and holy impression, this color symbolizes sincerity, kindness, sincerity, and perfection. Slobog batik motif, derived from the word lobog which means loose. Slobog batik motif is a geometric motif with a pattern of triangular motifs, whose shape is in the form of small squares separated by two lines, thus forming a motif of four triangular pieces. On one side of the motif that is separated by lines, there is a circle surrounded by six small spots. This slobog motif is one of the motifs in Batik Kitchen Café and Restaurant, which is applied to the floor and dining table. Slobog motif is a batik motif that is generally used as a dress in a mourning state. But at Batik Kitchen Café and Restaurant, it functioned as an aesthetic element in the room. The colors are black, beige, white and blue. Each color has its meaning. The black color has the impression of darkness. This color contains the symbolic meaning of grief, sorrow or sorrow, death, and extinction. Yellowish beige is a color that depicts softness, glory, and majesty. The white color has a clean, holy, and peaceful impression. The white color symbolizes purity, perfection, and sincerity. The blue color has a cool, and calm impression. This color symbolizes trust or loyalty, and tranquility.

\section{Conclusion}

Based on the results of research that has been done, it can be concluded that ornamental variety elements applied to the forming elements and space fillers in Batik Kitchen Café and Restaurant in Cirebon undergo some changes in functions, and changes in shape, thus affecting the meaning of each ornamental variety element. The application of ornamental variety elements in the interior style of Batik Kitchen Café and Restaurant in Cirebon has the main meaning and purpose, which is to introduce, lift, and preserve the value of tradition, and culture owned by the city of Cirebon. The author can only give advice for the next researcher who eagers to continue research at Batik Kitchen Café and Restaurant in Cirebon, it is suggested to examine the other parts of the café and restaurant that the researchers have not examined, one of which is the circulation system of Batik Kitchen Café and Restaurant in Cirebon.

\section{References}

Allen, G. (2004). Roland barthes. Routledge.

Borshalina, T. (n.d.). Anticipation in the Future Development of Trusmi Batik SMES at Cirebon Regency.

Docci, M., \& Chiavoni, E. (2014). Visione, pensiero, disegni: gli insegnamenti di Francis DK Ching=Vision, ideas, drawings: teachings by Francis DK Ching. Visione, Pensiero, Disegni: Gli Insegnamenti Di Francis DK Ching= Vision, Ideas, Drawings: Teachings by Francis DK Ching, 48-59.

Handayani, S. (2019). Batik Trusmi Produksi Sally Giovani. Institut Seni Indonesia Yogyakarta.

Lauer, D. A., \& Pentak, S. (2011). Design basics. Cengage Learning.

Nurhayati, E., \& Nurhidayah, Y. (n.d.). Multicultural Value in the Traditional Islamic Boarding School, Bina Insan Mulia (BIMA), Cirebon, Indonesia. Nadwa, 13(1), 165-178.

Nursalim, A., \& Sobandi, B. (2020). Revitalization of Keraton Cirebon Batik.

Ramdoni, D., Sugiharto, T., Permana, A., \& Nugraha, R. (2019). Implementation of the FAST Fast Corner Detection Algorithm (Feature Form Accelerated Segment Test) and Augmented Reality to Determine the Authenticity of Batik Case Study (Batik Trusmi) Cirebon. Balong International Journal of Design, 1(1).

Rosenthal, M. (2016). Qualitative research methods: Why, when, and how to conduct interviews and focus groups in 
pharmacy research. Currents in Pharmacy Teaching and Learning, 8(4), 509-516.

Shuang, G. A. O. (2012). Commodification of place, consumption of identity: The sociolinguistic construction of a 'global village'in rural China 1. Journal of Sociolinguistics, 16(3), 336-357.

Sumarno, S., \& Indarto, I. (2018). Desain Show Room Bagi Para Perajin Rotan DS. Trangsan, Kec. Gatak, Kab. Sukoharjo. Pendhapa, 9(2). https://doi.org/https://doi.org/10.33153/pendhapa.v9i2.2419

Sunarya, Y., \& Anas, B. (2011). The aspect of identity in modern batik priangan in the context of creative industry in the city of Bandung. 3rd CELT International Seminar, 19-20.

Tresnawati, N., Saleh, I., \& Wardani, S. (2020). Scientific reconstruction of local plants as the basic materials of Batik Natural Dyes. Journal of Physics: Conference Series, 1511(1), 12062.

Trihanondo, D., Endriawan, D., Haryotedjo, T., Putra, G. M., \& Machfiroh, R. (2021). Redefining Cirebon batik into an environmentally friendly icon of West Java. IOP Conference Series: Materials Science and Engineering, 1098(5), 52011.

Widodo, W., Soekarba, S. R., \& Kusharjanto, B. (2021). Pemaknaan Motif Truntum Batik Surakarta: Kajian Semiotik Charles W. Morris. Sutasoma: Jurnal Sastra Jawa, 9(2), 197-210. 